\title{
Climate Changes in Southern Patagonia (Santa Cruz, Argentina) Inferred From Lake Sediments: The Multi-Proxy Approach of SALSA
}

\author{
B. Zolitschka ${ }^{1}$, F. Schäbitz ${ }^{2}$, A. LüCKE ${ }^{3}$, M. Wille ${ }^{2}$, C. MAYR $^{3}$, C. Ohlendorf ${ }^{1}$, F. Anselmetti ${ }^{4}$, D. Ariztegui ${ }^{5}$, H. Corbella ${ }^{6}$, B. \\ Ercolano ${ }^{7}$, M. Fey ${ }^{1}$, T. Haberzettl ${ }^{1}$, N.I. Maidana ${ }^{8}$, G.E. Oliva ${ }^{9}$, M. Paez ${ }^{10}$ and G.H. Schleser ${ }^{3}$ \\ ${ }^{1}$ Geomorphology and Polar Research (GEOPOLAR), University of Bremen, 28359 Bremen, Germany; zoli@uni-bremen.de \\ 2Seminar for Geography and its Didactics, University of Cologne, 50931 Köln, Germany; frank.schaebitz@uni-koeln.de \\ ${ }^{3}$ Isotope Geochemistry and Paleoclimate - ICG V, Research Center Jülich, 52425 Jülich, Germany; a.luecke@fz-juelich.de \\ ${ }^{4}$ Geological Institute, ETH Zentrum, NO H 50, 8092 Zürich, Switzerland \\ 5 Institute Forel and Dept. of Geology and Paleontology, R. des Maraîchers 13, 1205 Genève, Switzerland \\ ${ }^{6}$ Argentine Museum of Natural History, Av. Angel Gallardo 470, C1405DJR Buenos Aires, Argentina \\ 7 Universidad Nacional de Patagonia Austral, Lissandro de La Torre 1070, 9400 Río Gallegos, Argentina \\ ${ }^{8}$ National University Buenos Aires, Dept. of Biodiversity and Experimental Biology, Ciudad Universitaria, 1428 Buenos Aires, Argentina \\ 9Instituto Nacional de Tecnología Agropecuaria (INTA) Estación Experimental Agropecuaria Santa Cruz, 9400 Río Gallegos, Argentina \\ ${ }^{10}$ National University Mar del Plata, Dept. of Biology, Funes 3350, 7600 Mar del Plata, Argentina
}

Southern South America, the only landmass between $38^{\circ} \mathrm{S}$ and the Antarctic Circle, offers a unique opportunity to reconstruct terrestrial paleoclimates in an area affected by shifts of polar and mid-latitude wind and pressure fields. It is one of the key regions suited to a better understanding of long- and short-term climate processes, supporting one of the major DEKLIM goals i.e. to improve climate predictability at global and regional scales. The Antarctic Circumpolar Current advecting cold air to the continent is a major factor controlling the climatic conditions of Patagonia. The DEKLIM project "South Argentinean Lake Sediment Archives and Modeling" (www.SALSA.unibremen.de) investigates lacustrine sediments with an integrated research strategy to understand ecosystem changes in space and time. In conjunction with results from DEKLIM-RESPIC, which studies ice cores from the EPICA drill site in Antarctica, new keys to the understanding of southern ocean atmosphere variability can be expected.

SALSA studies are carried out in the Pali Aike Volcanic Field (PAVF; Santa Cruz province, southern Patagonia, Argentina). The PAVF covers an area of $4500 \mathrm{~km}^{2}$ and is located west of the city of Río Gallegos, immediately north of the Strait of Magellan (Fig. 1). Volcanism is characterized by plateau-like lava flows with eruption dates between 0.17 and 3.78 Ma BP (Corbella, 2002), scoria cones and maars. A few maarlike structures contain permanent

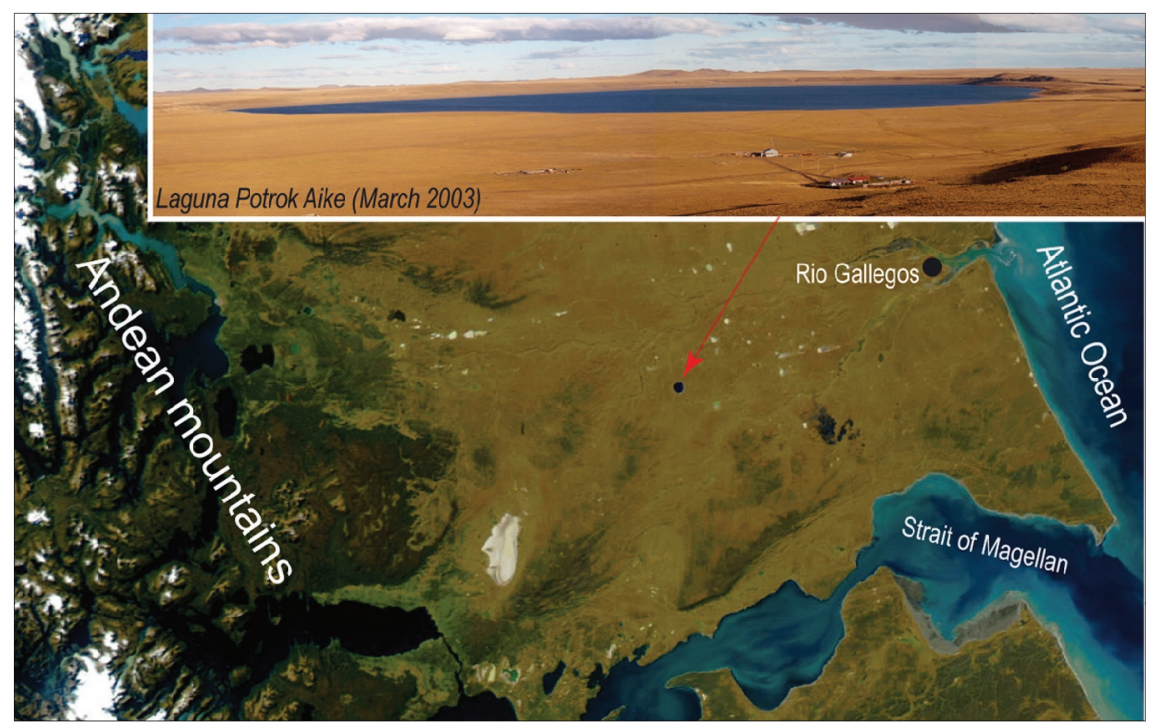

Fig. 1: Satellite image of southern Patagonia with the maar lake Laguna Potrok Aike in its center and an inserted photo of the same lake.

lakes varying from 500 to $3700 \mathrm{~m}$ in diameter and exhibiting up to $100 \mathrm{~m}$ water depth. The PAVF was not covered by Andean piedmont glaciers during the last glaciations. Thus, it is likely that long, continuous, continental paleoenvironmental and paleoclimatic records covering several glacial and interglacial cycles might be preserved in these volcanic lakes, which could be drilled in the framework of the International Continental Drilling Programme (ICDP). This would trigger a close cooperation with DEKLIM-EEM because it opens the possibility to study high resolution records of the same age and from the same depositional environment (maar lakes). As a first spin-off from the two cooperating DEKLIM projects SALSA and PROSIMUL, the project MIDHOL was launched in 2004. It aims to improve the understanding of climate variability in the time window $4500-6500$ years BP by running a transient simulation with a coupled atmosphere-ocean General Circulation Model.

\section{Environmental Setting}

The climate of south-eastern Patagonia is determined by the southern westerlies and the rain shadow of the Andes. Both factors lead to a dry continental climate with a strong precipitation gradient from $410 \mathrm{~mm}$ of annual precipitation in the west (RíoTurbio at the eastern foot of the Andes) to less than 150 $\mathrm{mm}$ at Laguna Potrok Aike in the PAVF. This precipitation gradient is crucial for vegetation patterns. The PAVF is covered with steppe vegetation of a moister type occurring mainly near the Andes and a drier type that occurs in the central and eastern parts of Santa Cruz and which dominates around the investigated lakes, Laguna Potrok Aike (supposedly a maar lake) and Laguna Azul (a crater lake). Nowadays, this vegetation 


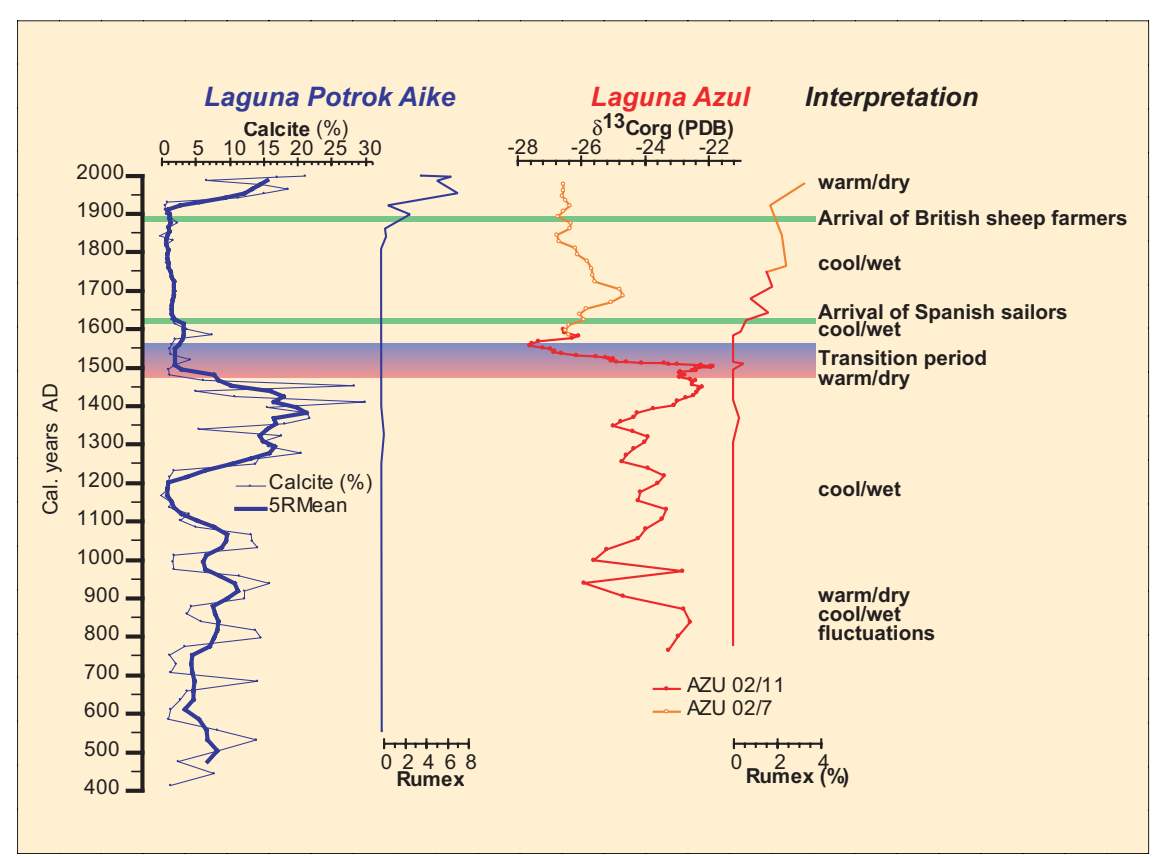

Fig. 2: Selected proxies from short sediment cores taken from Laguna Azul (red) and Laguna Potrok Aike (blue). Age is given in years $A D$ obtained by $A M S{ }^{14} \mathrm{C}$-dating and calibration with the southern hemisphere calibration curve. For Laguna Potrok Aike, the concentration of calcite (raw data and 5RMean = 5-point running mean) and the profile of Rumex pollen percentages are shown in blue. For Laguna Azul, $\delta^{13} \mathrm{C}$-values and Rumex pollen percentages are plotted in red. An interpretation referring to features that are detectable in both records is given on the right.

is strongly altered by sheep farming that commenced during the late $19^{\text {th }}$ century.

The lakes exhibit very different limnological characteristics (Zolitschka et al, submitted). For instance, Laguna Potrok Aike is relatively large (diameter $3700 \mathrm{~m}$, water depth $100 \mathrm{~m}$ ) and exposed to strong winds. With a specific conductivity of $3000 \mu \mathrm{S} / \mathrm{cm}$ and an alkalinity of $13 \mathrm{meq} / \mathrm{l}$, Laguna Potrok Aike is classified as a hardwater lake with a relatively high ionic concentration. In contrast, Laguna Azul is smaller (diameter $560 \mathrm{~m}$, water depth $56 \mathrm{~m}$ ) and wind protected by steep crater walls. Sediment records and morphology of the crater indicate a rather young (mid-Holocene) age for Laguna Azul. Specific conductivity and alkalinity of the lake water are rather low $(440 \mu \mathrm{S} / \mathrm{cm}, 4 \mathrm{meq} / \mathrm{l})$, pointing to different evaporation conditions at Laguna Azul compared to Laguna Potrok Aike.

\section{Sediments}

Gravity cores (up to $130 \mathrm{~cm}$ in length) from Laguna Potrok Aike and Laguna Azul have been studied. An integration of sedimentary parameters and dating (SALSA I), volcanic history (H. Corbella), fos- sil pollen (SALSA II), diatoms (N. Maidana), actual pollen rain (M. Paez), actual vegetation (INTA, Rio Gallegos), limnological and stable isotope (SALSA III) analyses yields the first multi-proxy paleoenvironmental reconstruction for this area. 22 AMS radiocarbon dates provide a chronological framework and indicate that the analyzed records of Laguna Potrok Aike $(100 \mathrm{~cm}, 13$ dates) and Laguna Azul $(130 \mathrm{~cm}$, 9 dates) cover the last 1600 and 1300 years, respectively. The palynological records of both lakes are dominated by pollen of regional Patagonian steppe taxa. However, a high amount of Andean forest taxa is remarkable, as the tree-line today is situated ca. $120 \mathrm{~km}$ west of Laguna Azul and ca. $60 \mathrm{~km}$ west of Laguna Potrok Aike. Although the limnological settings of the two lakes are different, there are indications that their sediments record similar environmental changes related to climate variability and human activities.

\section{Laguna Azul}

High concentrations of biogenic silica and $\mathrm{C} / \mathrm{N}$ ratios $<9$ in the sediments confirm a planktonic origin of sediment organic matter. Both parameters are strongly corre- lated with pollen concentrations of Patagonian steppe taxa. An interpretation integrating the data from Laguna Azul suggests that the climate became cooler after AD 1480 compared to a warmer interval between the $11^{\text {th }}$ and $15^{\text {th }}$ century (Mayr et al., submitted). In Figure 2 , the $\delta^{13} \mathrm{C}_{\text {org }}$-profile is shown as an example of lacustrine paleoproductivity. Cool climate conditions culminated around AD 1560 and prevailed until the end of the $16^{\text {th }}$ century. Despite a climatic amelioration in the $17^{\text {th }}$ and $18^{\text {th }}$ century, it remained cool until the start of the $20^{\text {th }}$ century. Since the middle of the $20^{\text {th }}$ century, proxies have shown a warming trend that caused the lake level to drop.

\section{Laguna Potrok Aike}

The calcite content in the sediment of Laguna Potrok Aike (Fig. 1) serves as a proxy for lake level changes (Fig. 2). Lake internal calcite precipitation depends on the ion concentrations in the lake water and thus reflects regional hydrological variations. The succession of moist/dry phases inferred from calcite-variations is supported by $\delta^{13} \mathrm{C}, \delta^{15} \mathrm{~N}$ and $\mathrm{C} / \mathrm{N}$ ratios (Haberzettl et al., submitted). Changes in these parameters represent varying input of the remains of water plants transported from shallow water habitats to the lake center and thus may also provide information about the lake level history. Between the $5^{\text {th }}$ and $11^{\text {th }}$ century, relatively frequent moist/dry fluctuations were noticed. Between the $11^{\text {th }}$ and $20^{\text {th }}$ century, conditions were relatively moist except for a dry period between the $13^{\text {th }}$ and $15^{\text {th }}$ century. The change from dry to moister conditions was dated to the $15^{\text {th }}$ century. Since the middle of the $20^{\text {th }}$ century, climate has been characterized by increasing drought.

\section{European Impact}

It has been one of the most important influences on South Patagonian ecosystems during the last centuries. The arrival of European sheep farmers at the end of the $19^{\text {th }}$ century initiated several feedback mechanisms leading to the degra- 


\section{Science Highlights: DEKLIM}

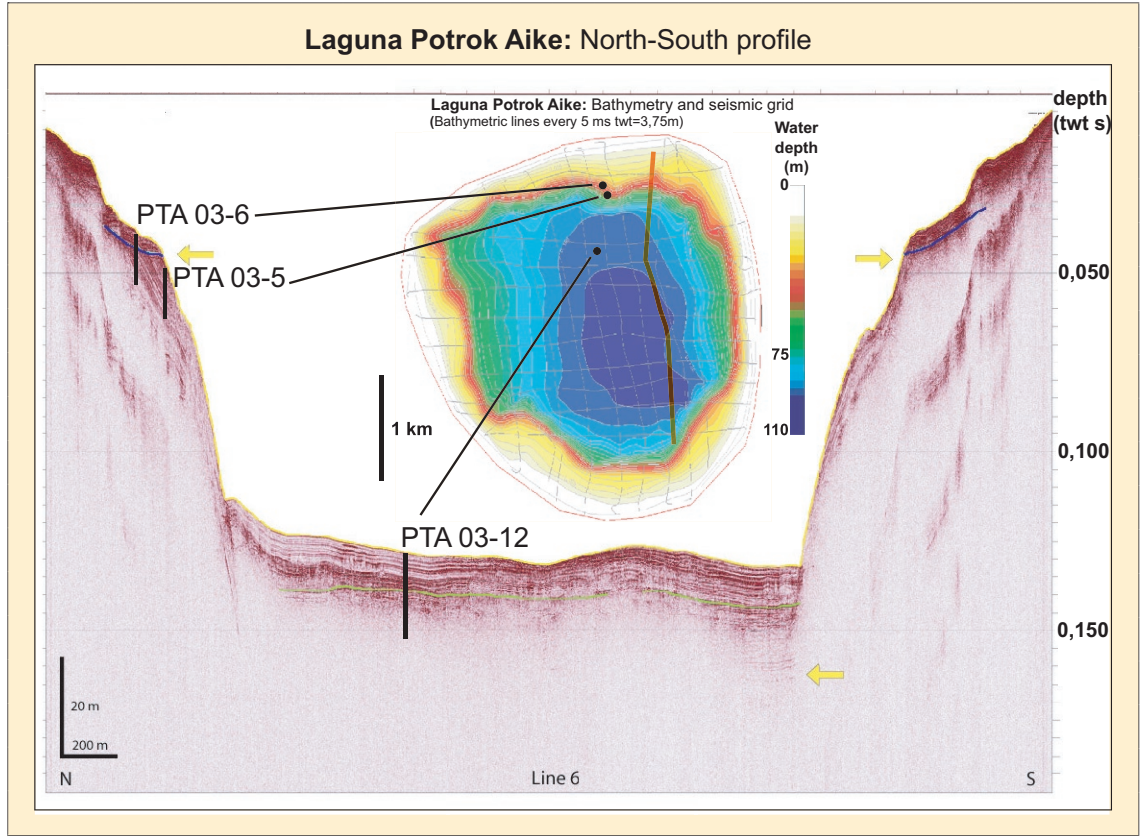

Fig. 3: Seismic profile through Laguna Potrok Aike (vertical exaggeration $=x 20$ ) and the positions of piston cores (see inset map for locations of seismic line, marked in red, and cores, marked as black dots). The flat central basin is limited by a steep rim. Note the lake shoulder above ca. $35 \mathrm{~m}$ water depth with a buried erosional unconformity (blue horizon, upper yellow arrows). A part of the basin floor is characterized by a greater depth of seismic subsurface penetration with deeper horizontal reflections (lower yellow arrow) down to $40 \mathrm{~m}$ of sediment depth.

dation of vegetation, the start of soil erosion and ultimately to increasing desertification. Major environmental changes due to sheep farming date back to the late $19^{\text {th }}$ century, as indicated by the occurrence of $R u$ mex pollen at Laguna Potrok Aike (Fig. 2). However, Rumex pollen occurs earlier at Laguna Azul (Fig. 2), probably related to colonization attempts by the Spaniards in the late $16^{\text {th }}$ century (Huber and Markgraf 2003).

\section{Sediment Records}

Examination of the sediment records from Laguna Potrok Aike and Laguna Azul has made possible the first reconstruction of regional paleoenvironmental history dating back to $A D 800$. Both records indicate that a major climate change from warm/dry conditions to cool/ wet conditions occurred during the $15^{\text {th }}$ century (Fig. 2). Since the middle of the $20^{\text {th }}$ century, the climate has been warmer and drier. Human impact is documented for two phases, at the end of the $16^{\text {th }}$ and at the end of the $19^{\text {th }}$ centuries.

\section{Perspectives}

The sediment record of Laguna Azul probably dates back to ca. for a much longer record. Seismic surveys carried out with a $3.5 \mathrm{kHz}$ system in 2003 and with an airgun system in 2004 demonstrate the presence of more than 30 to $40 \mathrm{~m}$ of undisturbed pelagic lake sediments. Continuous seismic reflections of the pelagic sediments are cut by steep crater slopes (Fig. 3). The seismic survey showed a topographic shoulder in the upper part of the slope. Here seismic data display a highly reflective pattern and a maximum penetration of around $15 \mathrm{~m}$. An erosional unconformity, marked as blue horizon in Figure 3 , persistently occurs around the entire lake cutting reflections of the underlying upper slope sections. The consistent water depth of the outcrop of the unconformity points to an ancient shore line formed by a lake level lowering of about $35 \mathrm{~m}$. On the other hand, terraces formed by wave action exposed up to $19 \mathrm{~m}$ above the present shore line point to periods with much higher lake levels in the past than today.

Physical properties (magnetic susceptibility, GRAPE density) measured for two cores (PTA 03/5, PTA 03/6) taken above and below the erosional unconformity (Fig. 3) display different sediment types. Additionally, the latter cannot be correlated to sediments from the central basin (PTA 03/12). Therefore, it is likely that these sediments were deposited in an earlier lake phase and are older than the strata recovered with the $18.9 \mathrm{~m}$ piston core from the central basin.

SALSA is scheduled for another two years in which the already taken long cores will be analyzed. Continuous sediment cores of 6.5 $\mathrm{m}$ from Laguna Azul and $18.9 \mathrm{~m}$ from Laguna Potrok Aike provide a promising source of information for the reconstruction of the Holocene and Late Glacial climate history of southernmost South America within the framework of DEKLIM. Furthermore, a seismic survey with a stronger acoustic source carried out in February 2004 clarified that the sediment infill of Laguna Potrok Aike exceeds $40 \mathrm{~m}$. Thus, Laguna Potrok Aike will be suggested as a target site for ICDP.

\section{References}

Corbella, H., 2002: El campo volcano-tectónico de Pali Aike. In: Haller M.J. (ed.), Geología y Recursos Naturales de Santa Cruz. Relatorio del XV Congreso Geológico Argentino. El Calafate. Buenos Aires, pp. 287-303.

Haberzettl, T., Fey, M., Lücke, A., Maidana, N., Mayr, C., Ohlendorf, C., Schäbitz, F., Schleser, G.H., Wille, M. and Zolitschka, B., submitted: Climatically induced lake level changes during the last two millennia as reflected in sediments of Laguna Potrok Aike, southern Patagonia (Santa Cruz, Argentina). Journal of Paleolimnology.

Huber, U.M. and Markgraf, V., 2003: European impact on fire regimes and vegetation dynamics at the steppe-forest ecotone of southern Patagonia. The Holocene 13:,567-579.

Mayr, C, Fey, M., Haberzettl, T., Lücke, A., Maidana, N.I., Ohlendorf, C., Schäbitz, F., Schleser, G.H. Wille, M. and Zolitschka, B., submitted: Climate changes during the last millennium in southern Patagonia - a 16th century cooling recorded in lake sediments from Laguna Azul (Argentina). The Holocene.

Zolitschka, B., Schäbitz, F., Lücke, A., Clifton, G. Corbella, H., Ercolano, B., Haberzettl, T., Maidana N., Mayr, C., Ohlendorf, C., Oliva, G., Paez, M.M., Schleser, G.H., Soto, J., Tiberi, P. and Wille, M., submitted: Paleoecological potential of crater lakes in the Pali Aike Volcanic Field, southern Patagonia (Argentina). Journal of South American Earth Sciences.

For full references please consult: www.pages-igbp.org/products/newsletters/ref2004_2.html 